\title{
Federal Non-Military Ownership
}

National Cancer Institute

\section{Source}

National Cancer Institute. Federal Non-Military Ownership. NCI Thesaurus. Code

C133309.

Owned by the federal government and receives federal government funding. 